\title{
EDUCATION FOR EMPOWERMENT AND SOCIAL ACTION IN RURAL AMERICA
}

\section{Reverend David Ostendorf}

Daniel Levitas

Prairiefire Rural Action, Inc.

Mid-American Review of Sociology, 1987, Vol. XII, No. 1:55-64

Education without social action is a one-sided value because it has no true power potential. Social action without education is a weak expression of pure energy. Deeds uninformed by educated thought can take false directions. When we go into action and confront our adversaries, we must be as armed with knowledge as they. Our policies should have the strength of deep analysis beneath them to be able to challenge the clever sophistries of our opponents.

From Where Do We Go From Here: Chaos or Community by Dr. Martin Luther King, Jr.

Prairiefire Rural Action, Inc. is an independent, non-profit, education, research and community action organization based in Des Moines, Iowa. Prairiefire was organized in February 1985, and employs a staff of eleven. Many of its staff and leaders have been actively involved in developing a regional and national grassroots response to the economic and social crisis in American agriculture and rural life since the early 1980s.

The organization's principle objectives include: keeping small and medium-size family farms in operation and farm families on the land; advocating on behalf of those farm and rural people who cannot be heard; revitalizing family farm agriculture in the U.S.; and building strong coalitions in support of family farm agriculture.

Prairiefire achieves these and other objectives by working directly with farm and rural families adversely affected by the current crisis and by engaging in community organizing, hotline counseling, citizen action, public policy research, and legal advocacy. Increasingly, Prairiefire staff have been called upon to educate and train the leaders and staff of farm, rural, and religious organizations responding to the crisis in their respective states and regions. 
After more than six years of what was initially referred to simply as "the farm crisis," conditions have now become chronic and more complex. As the crisis has evolved, so have the variety of techniques of educational intervention directed at those individuals and families in distress. The purpose of this paper is to describe both the underlying assumptions and results of the educational efforts of one grassroots, community-based organization, Prairiefire Rural Action, Inc.

Prairiefire's work is rooted in several premises: (1) that education is not value-neutral, and serves either to reinforce or change existing socio-economic and political relations of power; and (2), that the economic survival and future well-being of farm and rural people is a function of their knowledge of their legal and political rights and options to displacement, and a function of their subsequent political empowerment through organized action.

The goal of that education/empowerment process is to change institutions and public policies that adversely impact the lives of rural people and threaten family-farm agriculture, thereby increasing concentration of land ownership and control in the United States. Unlike most other educational processes that profess to be value-neutral or apolitical, the work of Prairiefire is "political" in the broadest sense of the word; i.e. it is to politicize people for effective participation in the democratic process of change and transformation. Prevailing educational theory and practice--especially institutional educational theory--from grade school through college is based primarily on adaptation to existing economic and political conditions. As Padfield (1980:170) reminds us in his incisive article on expendable rural communities, such adaptational theory, "handily reinforces the moral authority of the existing political and economic institutions that dominate if not totally control social environments."

Nurturing political consciousness or engendering political strategies is not a natural or comfortable task for educational institutions--be they universities, churches or independent agencies--and, in fact, usually generates instant conflict and controversy. But the journey of farm and rural people in America today is a political one that may and must shake some of the fundamental beliefs about how our economic system works. Our role in that journey involves providing tools and opportunities for people to understand and challenge those political and economic institutions that do, in fact, exercise control over their lives. This will enable them to use their own collective power to change the policies and practices of those institutions.
In the course of that work, we have consistently recognized a pervasive institutional tendency to "countersign rather than counteract" (Mueller, 1983) those powerful economic and political forces that have created the present crisis. We have also recognized that those who take a neutral or apolitical approach to education and "change" of ten end up reinforcing the relationships of power responsible for the unsettling of the Midwest in the first place.

This educational task is also not natural or comfortable for many of the people most directly affected by the crisis itself. In Pedagogy of the Oppressed, Paulo Friere reminds us that:

In their alienation, the oppressed want at any cost to resemble the oppressor, to imitate him, to follow him. This phenomenon is especially prevalent in the middleclass oppressed, who yearn to be equal to the "eminent" men of the upper class.

But Friere goes on to say that:

As long as the oppressed remain unaware of the causes of their condition, they fatalistically "accept" their exploitation. Further, they are apt to react in a passive and alienated manner when confronted with the necessity to struggle for their freedom and self-affirmation. Little by little, however, they tend to try out forms of rebellious action. In working towards liberation, one must neither lose sight of this passivity nor overlook the moment of awakening.

It is this "moment of awakening" that has been the focal point of the work of Prairiefire--and the work of many other similar organizations--since the crisis emerged more than five years ago. It is this "moment of awakening" that we have sought to nurture and build into a more lasting movement for economic and social justice and change in rural America. The following are examples of approaches to this process of education for action.

Farm Credit Advocacy as an Educational Strategy for Personal Empowerment and Institutional Change

Farm Credit Advocacy is the process whereby individuals, trained in both the techniques and technicalities of intervention, assist family farmers faced with the prospect of forced liquidation, bankruptcy, or foreclosure. The legal and financial framework of credit advocacy is complex, the emotional environment is highly 
unstable, and the need for new and accurate information constant. These factors, combined with the intense pressure brought about by the actions of creditors and their create a tremendously stressful environment for the advocate well as the farmer. Moving the advocacy process beyond simple resolution of an individual family's particular problem(s) to achieve institutional change is perhaps most challenging of all Through a combination of strategies involving hotline counseling individual sessions, public information meetings, and more visible media events, Prairiefire staff have helped fashion the structura framework of a successful advocacy approach.

In December 1982, Prairiefire staff initiated the formation of the Iowa Farm Unity Coalition's Farm Survival Hotline. ${ }^{1}$ Since that time the Hotline has handled more than 10,000 calls from farm and rural families in distress, primarily in the state of Iowa.

In cooperation with independent attorneys and the staff of the Legal Services Corporation of Iowa, approximately 25 day-long training sessions have been held throughout Iowa since 1983 designed to inform participants about strategies for aiding financially distressed farmers. A total of more than 250 advocates and attorneys participated in these events. Similarly, more than 100 educational meetings designed to convey information to farm and rural people about constructive alternatives to foreclosure have been conducted over the past several years by Prairiefire staff in communities throughout Iowa.

Individual families whose particular difficulties involved precedent-setting legal questions were encouraged and supported in their effort to pursue litigation. In at least one instance, such action helped precipitate the imposition of a nationwide two-year moratorium on government-initiated Farm and Home Administration (FmHA) foreclosures. Gary and Rosemary Barrett were denied most, if not all, of their administrative rights of due process by agency of ficials at the county, district, and state level. After appealing these adverse actions on numerous occasions they finally resorted to legal action and became one of a handful of plaintiffs in a successful nationwide class-action lawsuit against the agency.

Following a series of statewide and local meetings with borrowers from the cooperatively-owned Farm Credit System (FCS), local farmers within the Marshalltown area Federal Land Bank Association joined together in several meetings to confront local management in 1985-86. They passed resolutions calling for greater forbearance and fairer treatment of borrowers.
While it is certainly the case that neither the FmHA or FCS has entirely changed the manner in which they do business, both institutions have substantially modified their behavior. Publicity surrounding both farmers' grievances and the corresponding institutional responses (or lack thereof) have stimulated considerable public and political interest in the performance of both the FCS and the FmHA. This interest has also provoked a variety of internal changes within both agencies, resulting in the resignation or transfer of employees, greater internal accountability, and a fundamental reexamination of each agency's mission and purpose.

Farm Credit Advocacy is, then, largely an educational process. First, individuals are informed of their legal rights and options. Secondly, they are educated about the bureaucracy they confront--about their right of access to certain information, to question public officials, or challenge arbitrary decisions. Thirdly, they are given the tools to take action both individually and collectively.

The experience participants acquire from these attempts becomes part of the process of empowerment. Ultimately this experience enables them to achieve even greater success in effecting broader institutional change.

Defining a Public Policy Agenda for Rural Iowa: Education for StateLevel Reform

On February 2, 1987, Prairiefire and the Iowa Farm Unity Coalition launched a series of 19 meetings across Iowa designed to educate farm and rural people about state-level public policy reform. Nearly 1,000 individuals participated. ${ }^{2}$

Prior to the meetings, local contacts who would help publicize and facilitate the event were identified. Standardized materials which outlined the specific areas for discussion were made available to all meeting participants. Following a presentation outlining these topics, an extensive question-and-answer session covering everything from letter-writing to the technicalities of foreclosure reform was conducted. All participants subsequently received information about a variety of issues under consideration by the legislature in Des Moines. Those issues included limitations on farmland ownership by non family-farm entitles, foreclosure reform, and groundwater protection.

This initiative was, in fact, three-fold. First, it involved the solicitation of individual contacts on the local level. These contacts had to be well informed so as to be able to play a functional role in both the planning and execution of the local 
meeting. Secondly, information about events and issues pertinent to the concerns of meeting participants had to be conveyed in a manner that was reasonably easy to assimilate. Finally, by providing follow-up information to key participants, individuals were able to gain a better understanding of the legislative process itself. This final process of de-mystification is an essential component of the empowerment of a grassroots constituency.

In the months that followed more than fifty meeting participants travelled to Des Moines to talk with legislators. Many of the key issues that had been presented and discussed at the local meetings ultimately were debated and acted upon by the general assembly during the 1987 session. For example, a bill to allow large, non-farm corporations to purchase agricultural land for the purpose of poultry production--an activity currently prohibited under Iowa's "Family Farm Protection Act" (Chapter 172C Code of Iowa)--was soundly defeated. Measures to strengthen restrictions governing the activities of "authorized trusts" in the area of farmland ownership were also successful. And funding for the state's Farmer-Creditor Mediation Service--a major priority for grassroots coalition leaders during the 1986 legislative session--was secured.

\section{Building Constructive Responses to the Rural Radical Right Using Leadership Training}

The deteriorating rural economy throughout much of the Midwest and Plains States has provided fertile ground for the organizing efforts of a variety of far-right, racist, and anti-semitic groups and individuals. As the economic and social fabric of rural communities has become frayed, farmers have fallen victim to increased alienation and despair, making them prime targets for the propaganda of anti-semitic and neo-nazi organizations.

In August of 1985, leaders of the Center for Democratic Renewal $^{3}$ and Prairiefire initiated planning for a series of rural leadership training events focused on the development of constructive responses to the emergence of the rural radical right. These sessions, which have been held in the states of Iowa, Minnesota, Alabama, Nebraska, Missouri, Colorado, North Dakota, and Wyoming, have attracted more than 750 participants from 40 states and Canada, representing dozens of farm, rural, religious, civic, and law enforcement organizations and agencies.

The objectives of each session, as described in the letters of invitation sent to potential participants, were to:
* Define, in specific terms, the nature of the problem of the emergence of the rural radical right;

* Examine the recruitment techniques of the radical right and sharpen skills of rebuttal and analysis;

* Provide training, through panel presentations, small group discussions and role-plays, about the history and ideology of racism, fascism, and anti-semitism;

* Formulate concrete objectives for constructively confronting far-right elements in rural America as grassroots organizers, farmers, religious leaders, mental-health professionals, law-enforcement personnel, and civic activists committed to the principles of participatory democracy.

As an example, approximately 35 participants composed primarily of leaders from nine United Church of Christ regional conferences, attended a three-day session in Kansas City, Missouri in June, 1986. Following the event they embraced a threefold strategy for action. They committed themselves to:

* Assist victims of the farm crisis with personal, pastoral ministry;

* Create non-violent roadblocks to right-wing extremism by public exposure, community organization, and a prophetic ministry of sound biblical theology;

* Provide constructive alternatives for farm families to deal with their situations by addressing the appropriate legal, political, and economic institutions.

Another component of the educational effort to confront the rural radical right launched by Prairiefire staff has involved conducting numerous briefing sessions and lectures for groups such as the United Auto Workers Union, The Rocky Mountain Farmers Union, The Iowa Inter-Church Forum, among others. More than 2,500 individuals were reached directly through these forums during 1986.

These events resulted in considerable public exposure of the activities of the rural radical right, thereby forcing many of the key organizations and individuals involved onto the defensive. In 
some cases such exposure even forced the groups entirely underground, thereby impairing recruitment.

\section{CONCLUSION}

In his book The Populist Moment, historian Lawrence Goodwyn provides an important analysis of a social movement that, to this day, helps inform the work of individuals and organizations dedicated to economic and social justice.

. . .the 'movement'. . .was, in the most fundamental meaning of the word, 'ideological': it encouraged individuals to have significant aspirations in their own lives, it generated a plan of purpose, and a method of mass recruitment, it created its own symbols of politics and democracy in place of inherited hierarchical symbols, and it armed its participants against being intimidated by the corporate culture. The vision and hope embedded in the cooperative crusade held the agrarian ranks together while these things took place, and created the autonomous political outlook that was Populism.

While the analyses and successes of nineteenth century populism do not necessarily offer a comprehensive framework for addressing all of the complexities of late-twentieth century economic conditions, there is much to be learned from studying how the populists successfully achieved widespread reform. In the present day, similar reforms will only be won through work that is rooted in close and continuing contact with farm and rural families seèking relief from their own problems. Great importance must be placed on those aspects of the educational process that move individuals from a perspective of purely personal crisis to one of community response. Moving individuals from "coping" to "poking"--from mere adaptation to changing the prevailing power relationships is essential. The process must begin by enabling people to move from asking themselves the question, "How do. I save myself?" to "How do we save ourselves?" through organized action and institutional and political change. Empowerment must become the substitute for powerlessness.

Much has been accomplished in recent years through a process of education for empowerment and social action in rural America. But the challenge ahead into the twenty-first century is awesome. Even now those with the power of pen and purse are attempting to convince us that this crisis is over, and that the "economic recovery" is finally here. Indeed, the farm crisis as such may be quietly fading as more people are displaced from the land, but the systemic disparities in our economy are only now beginning to be experienced in depth by farm and rural people who face the prospects of displacement into the next generation.

American agriculture is moving rapidly toward a two-tier structure that reflects the emerging two-class structure of our society. In agriculture we will see the emergence of the few who own and control much at the expense of the many who will own or control little. As that phenomenon grows it will be even more difficult to engage in the process of educating and empowering those who face displacement or the steady deterioration of their economic position, for those with power will be positioned to define more clearly the terms of success and failure--the terms of survival.

The challenge faced by those who teach--professionally or otherwise--is whether or not we are able to stake our claim of solidarity with those who may be dispossessed and displaced, and to what degree we will serve the claim of the powerful upon us and our institutions. It is a challenge from which educators cannot shrink as we confront an extraordinarily unsettling future in the Midwest and throughout rural America. It is a challenge that is all the more important in light of our responsibility to empower rural people as we all struggle to understand and redefine the parameters of power operational in our lives and communities.

\section{FOOTNOTES}

1. The IFUC is composed of 13 member groups. These include the Iowa Farmers Union, United Auto Workers Union CAP Council; Iowa Inter-Faith Church Forum, Iowa NFO, and the Iowa AAM, to name a few.

2. Meetings were held in: Iowa Falls, Riverside, Vinton, Creston, Sheldon, Calmar, Denison, Charles City, DeWitt, Dyersville, Newton, Spencer, Atlantic, Fort Dodge, Shenandoah, Perry, Garner, and Holstein.

3. The Atlanta-based Center for Democratic Renewal is the leading national organization established to provide information and assistance about community-based responses to hate group activity. 


\section{REFERENCES}

Mueller, E.W.

1983 "The Holy Earth: The Church's Involvement in the Rural Life Movement." Grapevine (Joint Strategy and Action Committee), September.

\section{Padfield, Harland}

1980 "The Expendable Rural Community and the Denial of Powerlessness." In Art Gallagher Jr., and Harland Padfield (ed.), The Dying Community. Albuquerque, NM: The University of New Mexico Press.
EMPOWERING RURAL PEOPLE:

STRATEGIC PLANNING AND TRAINING FOR COMMUNITY SURVIVAL

\section{Susan Myers, Bruce Drewlow, Jackie Zerr} University of Minnesota, Morris

Mid-American Review of Sociology, 1987, Vol. XII, No. 1:65-80

Community Quest is a problem-solving model for rural communities which connects leadership development with local issues. Leadership is a lifelong pursuit, developed through practical experiences in our own communities. By building on community strengths, a region can clarify its collective mission to direct power and resources toward a shared vision. The goal is to link communities in a shared agenda for the region. Innovative techniques are used to involve more people in the community's decision-making process. A three-stage process which combines research and problem-solving methods brings decision makers and stakeholders together for strategic planning.

A community is always poised between its past and its future--while grounded in the present. Community Quest is a problem-solving model for rural communities which connects leadership development with local issues. The project grew out of insights on the importance of change being grounded in local communities to complement regional efforts. This grass roots community project pioneers new ways of encouraging the disadvantaged, the disenfranchised, and those negatively impacted by economic change to participate more fully in their community.

Its objectives are to: (1) work with leaders to identify community mission and build on community resources; (2) provide a forum for leaders to discuss public issues on their community's agendas; (3) identify each participant's leadership strengths and broaden leadership skills; and (4), celebrate individual and community achievements. The goal is to link communities in a shared agenda for the region. By building on community strengths, the region can clarify a collective mission to direct its power and resources to achieve a shared vision. The uniqueness of each participant is respected, as are the contexts in which they work. Commitment is built by encouraging individuals to recognize their 